\title{
Long-distance movement of a lone short-beaked common dolphin Delphinus delphis in the central Mediterranean Sea
}

\author{
TILEN GENOV ${ }^{1}$, GIOVANNI BEARZI ${ }^{2,3}$, SILVIA BONIZZONI ${ }^{2,3}$ AND MILENA TEMPESTA ${ }^{4}$ \\ ${ }^{1}$ Morigenos Marine Mammal Research \& Conservation Society, Jarška cesta 36/a, 1000 Ljubljana, Slovenia, ${ }^{2}$ Tethys Research \\ Institute, Viale G.B. Gadio 2, 20121 Milan, Italy, ${ }^{3}$ Dolphin Biology \& Conservation, Collebaldo 40, o6066 Piegaro PG, Italy, \\ ${ }^{4}$ WWF Italy, Miramare Marine Protected Area, Viale Miramare 349, 34151 Grignano, Trieste, Italy
}

\begin{abstract}
While short-beaked common dolphins are often regarded as highly mobile animals, their movements and ranging patterns are poorly known and no long-distance movements have been documented through photo-identification of individuals. We report the long-distance movement of a naturally marked individual, encompassing a minimum of $1000 \mathrm{~km}$ across the Ionian and the Adriatic Seas, and the subsequent behaviour and site fidelity of the same individual, in association with a calf, in and around the commercial port of Monfalcone, northern Adriatic Sea. This is the longest documented movement for any individual of this species, worldwide.
\end{abstract}

Keywords: short-beaked common dolphin, Delphinus delphis, movements, behaviour, photo-identification, Mediterranean Sea

Submitted 3 October 2011; accepted 22 October 2011

\section{INTRDDUCTION}

The short-beaked common dolphin Delphinus delphis (hereinafter 'common dolphin') has faced a major decline in abundance and distribution in the Mediterranean Sea in recent decades (Bearzi et al., 2003). In the coastal waters of Greece, a local population of common dolphins inhabiting the Inner Ionian Sea Archipelago has undergone a decline from around 150 animals in 1996 to only about 15 in 2007 (Bearzi et al., 2008), likely due to prey depletion resulting from overfishing (Bearzi et al., 2010; Gonzalvo et al., 2010; Piroddi et al., 2010). In the northern Adriatic Sea, common dolphins were historically abundant but had virtually vanished by the 1970s (Bearzi et al., 2003, 2004).

While common dolphins are often regarded as highly mobile animals, their movements and ranging patterns are poorly known (Natoli et al., 2006; Mirimin et al., 2009). To our knowledge, no long-distance movements have been documented through photo-identification of individually identifiable animals. This paper reports: (1) the long-distance movement of a naturally marked individual, encompassing a minimum of $1000 \mathrm{~km}$ across the Ionian and the Adriatic Seas; and (2) the subsequent behaviour and site fidelity of the same individual, in association with a calf, in and around the commercial port of Monfalcone, northern Adriatic Sea.

\section{METHDDS AND RESULTS}

In June 2010, an adult-calf pair of common dolphins-the adult a presumed mother-was observed in the port of

Corresponding author:

T. Genov

Email: tilen.genov@gmail.com
Monfalcone, an industrial town near Trieste (northern Adriatic Sea, $45047^{\prime} \mathrm{N} 13033^{\prime} \mathrm{E}$; Figure 1). These dolphins were repeatedly sighted there between June 2010 and January 2011, in an area of $1.2 \mathrm{~km}^{2}$. High-quality digital photographs of the dorsal fin of both animals were taken for individual photo-identification (Würsig \& Jefferson, 1990) and video footage was obtained on some occasions. The adult appeared in good physical condition, with no evidence of injuries, malnutrition or skin disease based on images of its dorsum. The calf-about half the length of the adultinitially appeared in good condition but started showing signs of emaciation by January 2011. It was estimated to be about one year old at the beginning of the observation period, based on a comparison with photographs of animals of known age taken in the Ionian Sea. In February 2011, the calf disappeared. After this, the adult was absent from the port on several occasions and could not be found in the adjacent waters within a $6 \mathrm{~km}$ radius. However, the animal returned to the port occasionally between February and May 2011. In May 2011, the adult was filmed $4.5 \mathrm{~km}$ from Monfalcone. In June, July and August 2011 it was observed repeatedly between Monfalcone and the city of Trieste (22 km south-east of Monfalcone), within $1 \mathrm{~km}$ of the coast. During some encounters, both inside and outside of the port, the animal was quite active, performing bowriding, leaps, breaches, side-slaps, tail-slaps and carrying jellyfish Rhizostoma pulmo between its pectoral fins while swimming belly-up at the surface. Some of the observed behaviours were suggestive of foraging and playing.

A comparison with a catalogue of 171 naturally marked common dolphins from the Inner Ionian Sea Archipelago, Greece (Bearzi et al., 2008), revealed that the adult was encountered there in August 2008, in a group composed of eight adults and one calf. Although most photo-identified animals in the Inner Ionian Sea Archipelago were sighted 


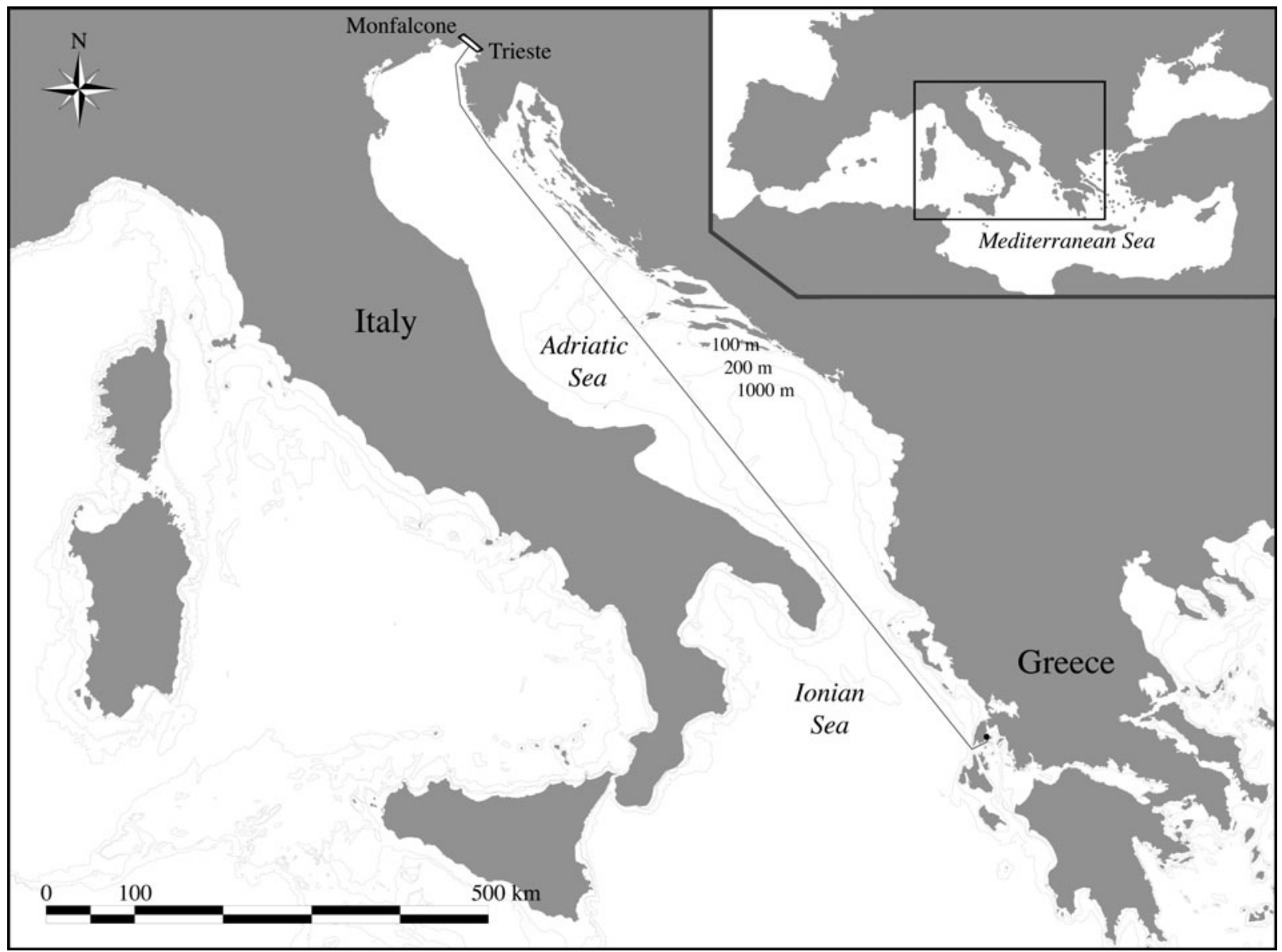

Fig. 1. Minimum distance travelled by the adult common dolphin, with some of the locations cited in the text.

regularly, this particular animal was encountered in that area only once. If moving in a straight line, the animal would have travelled a minimum of $1000 \mathrm{~km}$ between the two sites (Figure 1). This is the longest documented movement for any individual of this species, worldwide.

\section{DISCUSSIDN}

Common dolphins are generally thought to be wide-ranging. For example, a radio-tagged female common dolphin off the coast of California travelled at least $500 \mathrm{~km}$ in 10 days (Evans, 1982). Genetic studies of common dolphins in the Mediterranean Sea and North Atlantic Ocean further support the notion that these animals perform long-distance movements (Natoli et al., 2006). However, such movements have never been documented based on individual photo-identification, probably due to scarce application of this method to common dolphins (Neumann et al., 2002; Bearzi et al., 2011).

In most mammals dispersal is biased towards males (Greenwood, 1980). Females are usually philopatric while males tend to disperse. As revealed by genetics, this also appears to be the case in at least some populations of common bottlenose dolphins Tursiops truncatus (Möller \& Beheregaray, 2004), but not in others (Natoli et al., 2005). Genetic studies of short-beaked common dolphins from the Mediterranean and North Atlantic showed no marked differences in dispersal between sexes (Natoli et al., 2006, 2008).
The observation reported here refers to an individual that moved to a part of the Mediterranean Sea-the northern Adriatic Sea-where the species no longer occurs (Kryštufek \& Lipej, 1993; Bearzi et al., 2004; Genov et al., 2008). Additionally, this particular animal seems to have settled in a port for several months. Such behaviour is atypical for this species. Bottlenose dolphins frequently approach and enter ports and a number of single individuals have taken residence in urban areas (Lockyer, 1990; Eisfeld et al., 2010). Common dolphins, however, have rarely been reported to do that. One case involved the presence of two long-beaked common dolphins D. capensis in two small bays on the central coast of Chile for 10 years (Bernal et al., 2003). Given the circumstances, care must be taken in interpreting and assessing the ecological significance of the reported long-distance movement for Mediterranean common dolphins on the whole.

Still, this study indicates the value and the potential of photo-identification to gain insights into common dolphin movement and ranging patterns. Comparisons among the existing common dolphin photo-identification catalogues would therefore be worthwhile and may provide further insight.

\section{ACKNDWLEDGEMENTS}

We are grateful to Tina Centrih, Tommaso De Lorenzi, Sibilla Gerin, Ana Hace, Polona Kotnjek and Karin Schlappa for their 
help with field data collection. Annalise Petroselli took photographs of the adult common dolphin in the Inner Ionian Sea Archipelago. David Janiger helped with the literature. Ada Natoli, Bill Perrin, Karen Stockin and Ben Wilson provided useful comments and suggestions that helped improve the manuscript. We would also like to thank Ana Rita Amaral, Maddalena Bearzi, Simon Berrow, Massimo Celio, Saul Ciriaco, Antonio Codarin, Lisa Faresi, Erik Merson, Enrico Vinzi, ARPA FVG and the Coast Guards of Trieste and Monfalcone.

\section{REFERENCES}

Bearzi G., Agazzi S., Gonzalvo J., Bonizzoni S., Costa M. and Petroselli A. (2010) Biomass removal by dolphins and fisheries in a Mediterranean Sea coastal area: do dolphins have an ecological impact on fisheries? Aquatic Conservation: Marine and Freshwater Ecosystems 20, 549-559.

Bearzi G., Agazzi S., Gonzalvo J., Costa M., Bonizzoni S., Politi E., Piroddi C. and Reeves R.R. (2008) Overfishing and the disappearance of short-beaked common dolphins from western Greece. Endangered Species Research 5, 1-12.

Bearzi G., Bonizzoni S., Agazzi S., Gonzalvo J. and Currey R.J.C. (2011) Striped dolphins and short-beaked common dolphins in the Gulf of Corinth, Greece: abundance estimates from dorsal fin photographs. Marine Mammal Science 27, E165-E184.

Bearzi G., Holcer D. and Notarbartolo di Sciara G. (2004) The role of historical dolphin takes and habitat degradation in shaping the present status of northern Adriatic cetaceans. Aquatic Conservation: Marine and Freshwater Ecosystems 14, 363-379.

Bearzi G., Reeves R.R., Notarbartolo di Sciara G., Politi E., Cañadas A., Frantzis A. and Mussi B. (2003) Ecology, status and conservation of short-beaked common dolphins Delphinus delphis in the Mediterranean Sea. Mammal Review 33, 224-252.

Bernal R., Olavarría C. and Moraga R. (2003) Occurrence and long-term residency of two long-beaked common dolphins, Delphinus capensis (Gray 1828), in adjacent small bays on the Chilean central coast. Aquatic Mammals 29, 396-399.

Eisfeld S., Simmonds M. and Stansfield L. (2010) Behavior of a solitary sociable female bottlenose dolphin (Tursiops truncatus) off the coast of Kent, south-east England. Journal of Applied Animal Welfare Science $13,31-45$.

Evans Q. (1982) Distribution and differentiation of stocks of Delphinus delphis Linnaeus in the northeastern Pacific. In Mammals in the Seas: Small cetaceans, seals, sirenians, and otters, Volume 5. Rome: FAO, pp. 45-66.

Genov T., Kotnjek P., Lesjak J., Hace A. and Fortuna C.M. (2008) Bottlenose dolphins (Tursiops truncatus) in Slovenian and adjacent waters (northern Adriatic Sea). Annales, Series Historia Naturalis 18, 227-244.

Gonzalvo J., Moutopoulos D.K., Bearzi G. and Stergiou K.I. (2010) Fisheries mismanagement in a Natura 2000 area in western Greece. Fisheries Management and Ecology 18, 25-38.
Greenwood P.J. (1980) Mating systems, philopatry and dispersal in birds and mammals. Animal Behaviour 28, 140-162.

Kryštufek B. and Lipej L. (1993) Kiti (Cetacea) v severnem Jadranu. Annales, Series Historia Naturalis 3, 9-20.

Lockyer C. (1990) Review of incidents involving wild, sociable dolphins, worldwide. In Leatherwood S. and Reeves R.R. (eds) The bottlenose dolphin. San Diego, CA: Academic Press, pp. 337-353.

Mirimin L., Westgate A., Rogan E., Rosel P., Read A., Coughlan J. and Cross T. (2009) Population structure of short-beaked common dolphins (Delphinus delphis) in the North Atlantic Ocean as revealed by mitochondrial and nuclear genetic markers. Marine Biology 156, $821-834$.

Möller L.M. and Beheregaray L.B. (2004) Genetic evidence for sex-biased dispersal in resident bottlenose dolphins (Tursiops aduncus). Molecular Ecology 13, 1607-1612.

Natoli A., Birkun A., Aguilar A., Lopez A. and Hoelzel A.R. (2005) Habitat structure and the dispersal of male and female bottlenose dolphins (Tursiops truncatus). Proceedings of the Royal Society B: Biological Sciences 272, 1217-1226.

Natoli A., Cañadas A., Peddemors V.M., Aguilar A., Vaquero C., Fernandez-Piqueras P. and Hoelzel A.R. (2006) Phylogeography and alpha taxonomy of the common dolphin (Delphinus sp.). Journal of Evolutionary Biology 19, 943-954.

Natoli A., Cañadas A., Vaquero C., Politi E., Fernandez-Navarro P. and Hoelzel A.R. (2008) Conservation genetics of the short-beaked common dolphin (Delphinus delphis) in the Mediterranean Sea and in the eastern North Atlantic Ocean. Conservation Genetics 9, 14791487 .

Neumann D.R., Leitenberger A. and Orams M.B. (2002) Photoidentification of short-beaked common dolphins (Delphinus delphis) in north-east New Zealand: a photo-catalogue of recognisable individuals. New Zealand Journal of Marine and Freshwater Research 36, 593-604.

Piroddi C., Bearzi G. and Christensen V. (2010) Effects of local fisheries and ocean productivity on the north-eastern Ionian Sea ecosystem. Ecological Modelling 221, 1526-1544.

and

Würsig B. and Jefferson T.A. (1990) Methods of photo-identification for small cetaceans. In Hammond P.S., Mizroch S.A. and Donovan G.P. (eds) Individual recognition of cetaceans: use of photo-identification and other techniques to estimate population parameters. Report of the International Whaling Commission, Special Issue 12, Cambridge, UK, pp. $43-52$.

\section{Correspondence should be addressed to:}

T. Genov

Morigenos, Jarska cesta 36/a

1000 Ljubljana, Slovenia

email: tilen.genov@gmail.com 